\title{
PENGEMBANGAN RUBRIK PENILAIAN KINERJA (PERFORMANCE ASSESMENT) UNTUK MENGUKUR KOMPETENSI MAHASISWA MELAKUKAN PRAKTIKUM EKOLOGI TUMBUHAN
}

\author{
Aida Fitriani Sitompul \\ Jurusan Biologi FMIPA Universitas Neger Medan, Jalan Willem Iskandar Pasar V Medan Estate, Medan, \\ Sumatera Utara 20221 \\ Email : aiesitompul@yahoo.co.id
}

\begin{abstract}
ABSTRAK
Penelitian ini memaparkan tentang pengembangan rubrik penilaian kinerja (Performance Assesment) untuk mengukur kompetensi mahasiswa dalam melakukan praktikum ekologi tumbuhan. Tujuan penelitian ini adalah untuk memperoleh alat penilaian kinerja serta mengetahui respon mahasiswa terhadap penggunaan alat penilaian kinerja ini. Prosedur penelitian mengadaptasi langkah-langkah penelitian pengembangan dengan mengambil sampel 1 kelas. Sebelum alat penilaian kinerja (performance assesment) ini diaplikasikan kepada mahasiswa, terlebih dahulu dilaksanakan uji kelayakan oleh beberapa ahli. Hasil uji kelayakan menunjukan tingkat ketercapaian pada kualifikasi baik sehingga tidak perlu direvisi. Setelah melalui uji kelayakan, alat penilaian kinerja di ujicobakan secara terbatas kepada mahasiswa. Hasil penelitian menunjukan Rata-rata mahasiswa kompeten dalam melakukan praktikum perbedaan tempat tumbuh $(81,22 \%)$, intraspesifik dan interspesifik $(86,76 \%)$, alelopati $(90,06 \%)$, daur karbon $(91,04 \%)$ dan analisis vegetasi (metode kuadran) $(84,24 \%)$, dan suksesi $(88,02 \%)$. Dari hasil penelitian ini dapat disimpulkan bahwa penggunaan rubrik penilaian kinerja (Performance Assesment) ini dapat meningkatkan kompetensi mahasiswa dalam melakukan kegiatan praktikum ekologi tumbuhan.
\end{abstract}

Kata Kunci : Penilaian kinerja (Performance Assesment), penelitian pengembangan, ekologi tumbuhan

\section{PENDAHULUAN}

Praktikum merupakan bagian dari proses pembelajaran yang bertujuan agar mahasiswa mendapatkan kesempatan untuk menguji dan melaksanakan dalam keadaan nyata apa yang diperoleh dalam teori. Kegiatan praktikum merupakan latihan aktivitas ilmiah baik berupa eksperimen, observasi maupun demonstrasi yang menunjukan adanya ketertarikan antara teori dengan fenomena yang dilaksanakan baik di laboratorium maupun di luar laboratorium, (Rustaman, 2003). Kegiatan praktikum juga dapat memberikan pengalaman belajar secara nyata kepada mahasiswa dengan mengembangkan keterampilan dasar bekerja di laboratorium seperti scientist, serta memberikan mahasiswa kesempatan untuk berpartisipasi aktif sehingga memperoleh informasi dan kecakapan sains dengan cara observasi.

Dalam proses pembelajaran mahasiswa memang lebih tertarik dan termotivasi dengan pelaksanaan praktikum dibandingkan dengan proses belajar mengajar yang hanya dilaksanakan di kelas, dengan kegiatan praktikum siswa dapat melakukan observasi, membuat predikisi, membuat hipotesis, menganalisis data, dan membuat kesimpulan tentang konsep yang dipelajari melalui berbagai fakta langsung sehingga konsep tersebut menjadi lebih nyata dan bermakna bagi siswa, (Agustinus, 2008). Seiring dengan lebih banyaknya kegiatan praktikum maka kegiatan penilaian pun harus dilakukan, yaitu dengan penilaian kinerja.

Penilaian kinerja (performance assesment) adalah proses mengumpulkan data dengan cara pengamatan yang sistematik untuk membuat keputusan tentang individu. Penilaian kinerja terutama sangat sesuai dalam menilai keterampilan. Keterampilan mahasiswa yang dapat dinilai meliputi keterampilan proses intelektual (seperti keterampilan observasi, berhipotesis, menerapkan konsep, merencanakan serta melakukan penelitian, dan lain-lain).

Penilaian kinerja sangat tepat bila digunakan dalam kegiatan praktikum. Bentuk penilaian kinerja yaitu kinerja klasikal, asesmen kinerja kelompok, asesmen kinerja personal. Penilaian kinerja tidak menggunakan kunci jawaban dalam menentukan skor, melainkan menggunakan pedoman penskoran berupa rubrik. 
Untuk menjamin reliabilitas, keadilan dan kebenaran penilaian maka perlu dikembangkan kriteria atau rubrik untuk pedoman menilai hasil kerja. Penilaian kinerja tidak hanya bergantung pada jawaban benar atau salah. Sebagaimana halnya dengan asesmen bentuk essay, observasi yang dilakukan oleh guru dalam rangka melakukan pertimbangan-pertimbangan subyektif berkenaan dengan level prestasi yang dicapai siswa. Evaluasi ini didasarkan pada perbandingan kinerja siswa dalam mencapai standar excellent (keunggulan, prestasi) yang telah dicapai sebelumnya (UPI, 2011).

Praktikum Ekologi Tumbuhan ini perlu penekanan pada pemberian pengalaman secara langsung, karena itu mahasiswa perlu dibantu untuk mengembangkan sejumlah kompetensi yang mereka miliki. Penilaian yang selama ini dilakukan oleh dosen hanya sebatas memperhatikan hasil ulangan tertulis yang hanya mengamati ranah kognitif, sedangkan ranah afektif dan psikomotor kurang mendapat perhatian. Ranah afektif dan psikomotor pun harus diamati kemajuannya seperti keterampilan menggunakan alat-alat, kemampuan menganalisis dan melaksanakan prosedur kerja sampai selesai, kemampuan mengambil keputusan, berdasarkan aplikasi yang diberikan dan kemampuan membaca menggunakan diagram, gambar, dan grafik. Kedua ranah tersebut tidak mungkin dapat di ketahui hanya dengan tes tertulis pada ulangan akan tetapi harus dengan penilaian kinerja (Performance Assesment) sesuai dengan rubrik tes perbuatan atau bahkan dengan dalam bentuk non tes misalnya dengan mengadakan kuliah lapangan.

Penilaian kinerja yang dilakukan dalam penelitian ini, merupakan proses penilaian yang menilai mahasiswa dalam kegiatan praktikum. Dengan kata lain yang dinilai dalam aktivitas pembelajaran mahasiswa adalah proses mahasiswa dalam praktikum ekologi tumbuhan, juga hasil yang telah dicapai siswa dari kegiatan kinerja yang telah dilakukan oleh mereka. Oleh karena itu, dalam kegiatan penilaian kinerja ini mahasiswa harus berupaya untuk menunjukan keterampilan yang mahasiswa kuasai dalam kompetensi yang menjadi standar penilaian. Selain mahasiswa dinilai ketika proses kegiatan belajar mengajar, juga hasil karya yang dibuat oleh mahasiswa harus menjadi bagian dari penilaian juga. Penilaian kinerja juga berguna bagi dosen diantaranya untuk menilai hasil belajar mahasiswa, membangun/membentuk kriteria-kriteria untuk memastikan evaluasi yang dibuat tidak menimbulkan kesalahan dan menentukan berbagai keterampilan yang dapat membentuk karateristik mahasiswa.

Bentuk pengembangan Rubrik Penilaian Kinerja (Performance Assesment) ini dirancang oleh penulis yang disesuaikan dengan silabus perkuliahan dan memperhatikan kebutuhan dan kemampuan mahasiswa dalam pelaksanaan praktikum. Hal ini yang melatar belakangi peneulis untuk melakukan penelitian dengan judul "Pengembangan Rubrik Penilaian Kinerja (Performance Assesment) untuk Mengukur Kompetensi Mahasiswa Melakukan Praktikum Ekologi Tumbuhan". Sehingga dengan pengembangan Rubrik Penilaian Kinerja (Performance Assesment) dapat mendukung dan meningkatkan minat serta memotivasi mahasiswa dan memberikan pengaruh positif dalam menumbuh kembangkan sikap ilmiah mahasiswa.

\section{METODE}

Penelitian ini adalah riset dan pengembangan pendidikan (Educational Research and Development, $R \& D$ ). Pengembangan yang meliputi tiga langkah utama yaitu : analisis kebutuhan, perancangan dan pengembangan rubrik, dan validasi serta reliabilitas perangkat asesmen yang meliputi uji coba, revisi dan validasi perangkat rubrik. Tahapan pengembangan perangkat asesmen kompetensi praktikum ekologi tumbuhan melalui rancangan R\&D . Desain penelitian ini meliputi pengembangan rubrik asesmen, validitas serta reliabilitas melalui uji coba di lapangan. Sementara studi pendahuluan mengenai analisis kebutuhan tidak disampaikan pada kesempatan ini.

Pada tahap pengembangan rubrik assesmen, dilakukan analisis kebutuhan untuk mengetahui keinginan dan kebutuhan mahasiswa peserta perkuliahan dari pelaksanaan perkuliahan praktikum ekologi tumbuhan kemudian merumuskan indikator dan kriteria 
ketercapaiannya, serta merancang draf perangkat asesmen untuk mengukur kompetensi praktikum ekologi tumbuhan. Pada pengembangan draf, untuk rubrik asesmen berdasarkan kebutuhan yang telah dianalisis, maka untuk praktikum ekologi tumbuhan difokuskan pada kompetensi melakukan praktikum lapangan.

Skala penilaian dalam setiap butir rubrik yang merupakan indikator kinerja yang harus dilakukan oleh mahasiswa sewaktu melakukan suatu tindakan dalam praktikum ekologi tumbuhan yaitu skor 4,3,2,1, jika kompetensi dilakukan dengan benar dan sempurna, skor 4, jika kompetensi dilakukan dengan benar tetapi kurang sempurna 3, jika kompetensi dilakukan dengan kurang benar sekor 2 dan skor 1 jika kompetensi tidak muncul sama sekali atau tidak dilakukan.

Pada tahap ini dilakukan juga jugmen pakar dari pakar asesmen dan pakar biologi, tentang draf perangkat asesmen dan revisi secara terbatas. Selain itu kepada mahasiswa secara perorangan meminta untuk memberikan pendapatnya tentang kejelasan dan kepahaman dari isi rubrik. Pada langkah ini disusun tugas (task), kriteria dalam bentuk kerja dan lembar pengamatan kinerja mahasiswa dalam bentuk daftar cek untuk mengukur kompetensi kinerja praktikum ekologi tumbuhan. Revisi dilakukan atas masukan dari pakar dan mahasiswa. Selanjutnya dilakukan uji coba dan revisi, dalam uji coba mahasiswa secara perorangan melakukan praktikum, dan rubrik yang sudah direvisi merupakan alat untuk mengumpulkan data. Teknik pengumpulan data melalui observasi langsung terhadap kinerja mahasiswa melakukan praktikum dengan menggunakan rubrik asesmen kinerja (performance assessment).

Analisis data dalam penelitian ini adalah deskriptif, yaitu menjelaskan suatu permasalahan gejala, atau keadaan sebagaimana adanya dan bukan menguji hipotesa. Data yang diperoleh dalam penelitian ini adalah data kualitatif yang diperoleh dari jawaban angket yang diisi oleh mahasiswa dan tim ahli. Data diperoleh berupa daftar check list yang dirangkum dalam bentuk tabel skala penilaian yang digunakan adalah skala 1-4, dengan keterangan (1) tidak sesuai, (2) kurang sesuai, (3) sesuai dan (4) sangat sesuai.
Selanjutnya menghitung tingkat kelayakan dan kesesuaian dengan menggunakan rumus:

Presentase skor

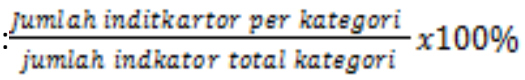

\section{HASIL PENELITIAN}

Produk yang dihasilkan dalam penelitian ini adalah alat penilaian kinerja (Performance Assesment) untuk menilai kegiatan mahasiswa dalam pembelajaran praktikum ekologi tumbuhan. Penilaian kinerja ini berisikan kategori penilaian yang diambil dari materi praktikum ekologi tumbuhan yaitu perbedaan tempat tumbuh, intraspesifik dan interspesifik, alelopati, daur karbon dan analisis vegetasi (metode kuadran), dan suksesi. Dengan adanya rubrik penilaian kinerja ini membantu mempermudah dosen dalam melakukan penilaian mahasiswa. Penilaian kinerja ini menggunakan pedoman penilaian atau rubrik penilaian kinerja. Dalam tahap pengembangannya, alat penilaian kinerja ini telah melalui validasi ahli dan ujicoba terbatas pada satu kelas. Masingmasing materi dikembangkan beberapa kompetensi/indikator sesuai dengan apa yang akan diobservasi. materi dan kompetensi/indikator yang telah dibuat dikonsultasikan pada ahli.

\section{Penilaian Instrumen Penilaian Kinerja \\ (Performance Assessment) Berdasarkan Ahli}

Untuk mengetahui kesesuaian dan kebermaknaan alat penilaian kinerja yang sudah dihasilkan dalam tahap pengembangannya alat penilaian kinerja ini telah melalui ujicoba. Uji coba ini dilakukan dengan melibatkan uji validasi ahli sebanyak tiga orang yaitu Drs. Zulkifli Simatupang (dosen 1), M.Pd, Drs. Puji Prastowo M.Si (dosen 2) dan Endang Sulistyarini Gultom, S.Si, M.Si, Apt (dosen 3).

Hasil validasi rubrik melalui masukan ahli yang dikumpulkan melalui format penilaian. Ahli memberikan penilaian rerata baik dan sangat baik terhadap butir-butir rubrik keterampilan dasar praktikum ekologi tumbuhan. Penilaian tim ahli memberikan penilaian rerata baik dan sangat baik terhadap butir-butir rubrik keterampilan dasar mengajar secara rinci, Pakar dan stakeholders memberikan penilaian rerata baik dan sangat baik 
terhadap butir-butir rubrik keterampilan dasar mengajar secara lebih umum, kecuali unit jaminan mutu dengan penilaian rerata antara cukup dan baik.

Penilaian instrumen penilaian kinerja (performance assessment) berdasarkan beberapa ahli dari aspek format penilaian kinerja skor keseluruhan adalah 48 dengan persentase $92 \%$ dan dengan keterangan sangat baik. Model skor penilaian sudah baik. Pada pernyataan ini skor keseluruhan adalah 48 dengan persentase 90\% dan dengan keterangan sangat baik. Aspek-aspek yang dinilai sudah memenuhi kriteria. Berikut hasil uji validasi ahli terhadap intrumen penilaian kinerja.

Tabel 1. Presentase Rata-rata Penilaian Instrumen Penilaian Kinerja (Performance Assessment) Berdasarkan Ahli

\begin{tabular}{lccc}
\hline \multicolumn{1}{c}{ Aspek Yang Dinilai } & Skor & Persentasi & Kategori \\
\hline Format penilaian kinerja & 48 & $92 \%$ & Sangat baik \\
\hline Model skor penilaian & 48 & $90 \%$ & Sangat baik \\
\hline Kriteria Aspek yang dinilai & 50 & $85 \%$ & Baik \\
\hline Aspek yang dinilai & 50 & $87 \%$ & Baik \\
\hline Format penilaian & 50 & $92 \%$ & Sangat baik \\
\hline Penulisan dan susunan kalimat & 45 & $90 \%$ & Baik \\
\hline $\begin{array}{l}\text { Aspek sesuai dengan kompetensi } \\
\text { mahasiswa }\end{array}$ & 45 & $90 \%$ & Sangat baik \\
\hline $\begin{array}{l}\text { Aspek sangat cocok untuk menilai } \\
\text { kegiatan praktikum. }\end{array}$ & 52 & $92 \%$ & Sangat baik
\end{tabular}

Pada pernyataan ini skor keseluruhan adalah 50 dengan persentase $85 \%$ dan dengan keterangan baik. Aspek penilaian sudah tepat. Pada pernyataan ini skor keseluruhan adalah 50 dengan persentase $85 \%$ dan dengan keterangan baik. Format penilaian kinerja mudah digunakan. Pada pernyataan ini skor keseluruhan adalah 50 dengan persentase $82 \%$ dan dengan keterangan baik. Penulisan dan susunan kalimat sudah baik. Pada pernyataan ini skor keseluruhan adalah 45 dengan persentase $90 \%$ dan dengan keterangan sangat baik. Urutan aspek penilaian sesuai dengan alur pelaksanaan praktikum. Pada pernyataan ini skor keseluruhan adalah 45 dengan persentase 92\% dan dengan keterangan sangat baik. Aspek penilaian dalam penilaian kinerja sesuai dengan kompetensi siswa. Pada pernyataan ini skor keseluruhan adalah 50 dengan persentase 85\% dengan keterangan baik. Alat penilaian kinerja ini sangat cocok untuk menilai kegiatan praktikum. Pada pernyataan ini skor keseluruhan adalah 52 dengan persentase $92 \%$ dan dengan keterangan sangat baik.

Dengan adanya validitas dari ahli instrumen penilaian kinerja (performance assessment) memastikan bahwa instrumen yang disusun sesuai dengan kurikulum yang berlaku sesuai dengan pendapat Belawati (2006) bahwa fokus validasi isi adalah mengukur konstruk atau komponen kelayakan isi yaitu keterkaitan SK dan KD pelajaran. Penyajian dan rancangan perlu diperhatikan untuk menunjukkan kualitas fisik yang menarik sehingga mampu mendukung proses pembelajaran/praktikum. 
Halaman : $282-289$

Tabe1 2. Format Instrumen Penilaian Kinerja (Performance Assesment) pada materi suksesi.

\begin{tabular}{|c|c|c|c|c|c|c|c|}
\hline \multirow[t]{2}{*}{ No } & \multirow[t]{2}{*}{ Tahapan } & \multirow{2}{*}{\multicolumn{2}{|c|}{ Aspek }} & \multicolumn{4}{|c|}{ Skor } \\
\hline & & & & 4 & 3 & 2 & 1 \\
\hline 1 & $\begin{array}{l}\text { Persiapan } \\
\text { Praktikum }\end{array}$ & 1.1 & $\begin{array}{l}\text { Mempersiapkan perlengkapan praktikum } \\
\text { sesuai dengan SOP } \\
\text { a. Menggunakan baju praktikum } \\
\text { b. Mempersiapkan penuntun } \\
\text { praktikum dan literatur } \\
\text { c. persiapan alat dan bahan praktikum } \\
\text { dengan benar dan lengkap } \\
\text { d. Mengidentifikasi tujuan praktikum }\end{array}$ & $\begin{array}{l}\text { Point } a, b, c \\
\text { dan } d \\
\text { terpenuhi }\end{array}$ & $\begin{array}{l}\text { Jika salah } \\
\text { satu point } \\
\text { tidak } \\
\text { terpenuhi }\end{array}$ & $\begin{array}{l}\text { Jika hanya } \\
\text { dua point } \\
\text { yang } \\
\text { terpenuhi }\end{array}$ & $\begin{array}{c}\text { Hanya } \\
\text { salah satu } \\
\text { saja point } \\
\text { yang } \\
\text { terpenuhi }\end{array}$ \\
\hline 2 & $\begin{array}{l}\text { Pelaksana } \\
\text { an } \\
\text { praktikum }\end{array}$ & 2.1 & $\begin{array}{l}\text { Prosedur kerja praktikum sesuai dengan } \\
\text { SOP } \\
\text { a. Mempersiapakan lahan yang akan } \\
\text { digunakan untuk suksesi } \\
\text { b. Melakukan pengukuran lahan seluas } \\
5 \times 5 \mathrm{~m}^{2} \text { kemudian membagi petak } \\
\text { menjadi } 1 \times 1 \mathrm{~m}^{2} \text { dengan tepat } \\
\text { c. Mengdentifikasi jenis tanaman pada } \\
\text { masing-masing petak secara tepat } \\
\text { d. Membersihkan lahan yang telah } \\
\text { diukur dengan tepat }\end{array}$ & $\begin{array}{l}\text { Jika point } \\
\text { a,b,c dan } \\
\text { d } \\
\text { dilaksanak } \\
\text { an secara } \\
\text { sistematis } \\
\text { dan tepat }\end{array}$ & $\begin{array}{l}\text { Jika point } \\
\text { a, b, c } \\
\text { terlaksana } \\
\text { secara } \\
\text { sistematis } \\
\text { sedangka } \\
\text { n point d } \\
\text { tidak } \\
\text { dilaksanak } \\
\text { an dengan } \\
\text { tepat }\end{array}$ & $\begin{array}{c}\text { Jika hanya } \\
\text { point a,b } \\
\text { yang } \\
\text { dilaksanak } \\
\text { an secara } \\
\text { sistematis } \\
\text { sedangka } \\
\text { n point c } \\
\text { dan d } \\
\text { tidak } \\
\text { dilaksanak } \\
\text { an }\end{array}$ & $\begin{array}{l}\text { Hanya } \\
\text { salah satu } \\
\text { point saja } \\
\text { yang } \\
\text { dilaksanak } \\
\text { an dengan } \\
\text { tepat }\end{array}$ \\
\hline & & 2.2 & $\begin{array}{l}\text { Pengamatan suksesi } \\
\text { a. Mengidentifikasi jenis tanaman pada } \\
\text { masing-masing petak } \\
\text { b. Menghitung jumlah masing-masing } \\
\text { spesies tanaman } \\
\text { c. Percobaan dilakukan dengan } \\
\text { berhasil } \\
\text { d. Membuat data pengamatan } \\
\text { sementara }\end{array}$ & $\begin{array}{l}\text { Jika } \\
\text { pengamat } \\
\text { an } \\
\text { dilakukan } \\
\text { secara } \\
\text { sistematis } \\
\text {, tepat, } \\
\text { dan } \\
\text { akurat }\end{array}$ & $\begin{array}{l}\text { Jika } \\
\text { pengamat } \\
\text { an } \\
\text { dilakukan } \\
\text { sudah } \\
\text { secara } \\
\text { sistematis } \\
\text {, tepat, } \\
\text { tetapi } \\
\text { kurang } \\
\text { akurat }\end{array}$ & $\begin{array}{l}\text { Jika } \\
\text { pengamat } \\
\text { an } \\
\text { dilakukan } \\
\text { tetapi } \\
\text { belum } \\
\text { secara } \\
\text { sistematis } \\
\text {, tepat, } \\
\text { dan } \\
\text { akurat }\end{array}$ & $\begin{array}{l}\text { Jika } \\
\text { pengamat } \\
\text { an tidak } \\
\text { dilakukan } \\
\text { secara } \\
\text { sistematis } \\
\text {, tepat, } \\
\text { dan } \\
\text { akurat. }\end{array}$ \\
\hline & & 2.3 & $\begin{array}{l}\text { Penggunaan waktu } \\
\text { a. Tidak melakukan kegiatan lain diluar } \\
\text { praktkum } \\
\text { b. Menggunakan waktu praktikum } \\
\text { secara efektif } \\
\text { c. Menyelasaikan praktikum tepat } \\
\text { waktu }\end{array}$ & $\begin{array}{l}\text { Jika } \\
\text { praktikum } \\
\text { diselesaik } \\
\text { an secara } \\
\text { efisien, } \\
\text { efektif } \\
\text { dan tepat } \\
\text { waktu }\end{array}$ & $\begin{array}{l}\text { Jika } \\
\text { praktikum } \\
\text { diselesaik } \\
\text { an secara } \\
\text { efisien } \\
\text { dan } \\
\text { efisien, } \\
\text { tetapi } \\
\text { tidak } \\
\text { tepat } \\
\text { waktu }\end{array}$ & $\begin{array}{l}\text { Jika } \\
\text { praktikum } \\
\text { diselesaik } \\
\text { an kurang } \\
\text { efektif, } \\
\text { efesien, } \\
\text { dan tidak } \\
\text { tepat } \\
\text { waktu }\end{array}$ & $\begin{array}{l}\text { Jika } \\
\text { praktikum } \\
\text { diselesaik } \\
\text { an tidak } \\
\text { efekti, } \\
\text { efisien, } \\
\text { dan tepat } \\
\text { waktu }\end{array}$ \\
\hline
\end{tabular}




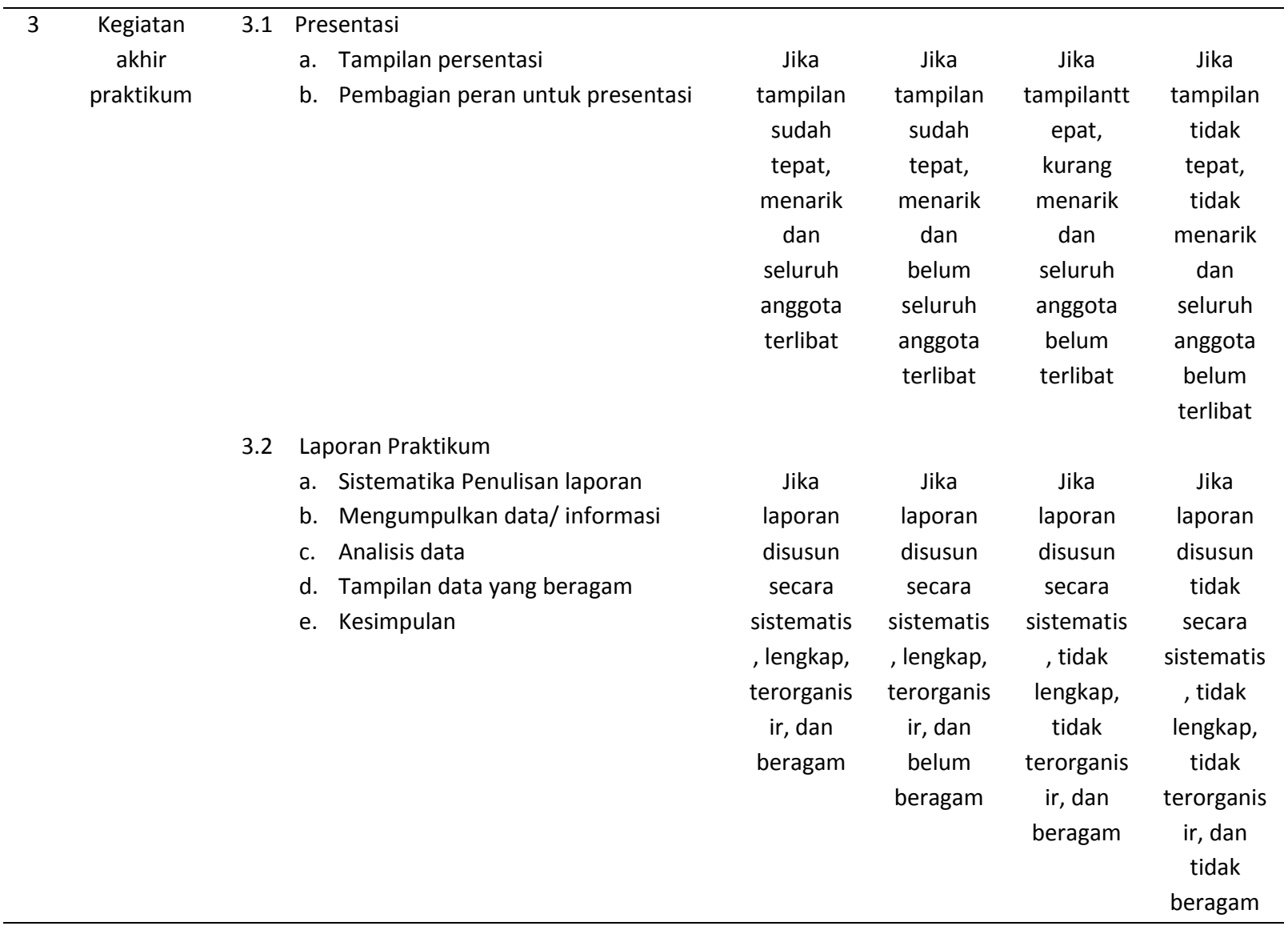

Format instrumen penilaian kinerja (Performance Assesment) pada tabel di atas hanya di wakili materi suksesi. Untuk semua materi yang membedakan pada kegiatan tahap pelaksanaan praktikum sedangkan tahapan persiapan dan tahap akhir kegiatan praktikum aspek penilaian sama, sehingga penulis hanya menampilkan satu materi saja. Para pakar memandang bahwa kelogisan format dan isi dari aspek serta kompetensi/indikator pada rubrik sudah memadai dan baik. Revisi dilakukan terutama pada beberapa kompetensi/indikator yang belum tegas. Pakar memberikan beberapa perbaikan yang masih bias.

$$
\text { Uji kejelasan dari setiap }
$$

kompetensi/indikator pada rubrik kompetensi melakukan praktikum ekologi dilakukan dengan cara meminta kepada mahasiswa untuk memberikan tanggapan apakah pernyataan dalam kompetensi/indikator sudah dipahami atau tidak. Untuk mengkaji pernyataan kompetensi/ indikator pada rubrik meminta sejumlah $(\mathrm{n}=38)$ mahasiswa untuk mengisi lembar penilaian kejelasan dan keterbacaan. Ketiga puluh delapan mahasiswa ini diminta untuk membaca satu persatu pernyataan aspek dan kompetensi/ indikator dan sekaligus disediakan mahasiswa untuk memberikan sarannya. Persentase mahasiswa yang memahami pernyataan dari setiap pernyataan ditunjukkan pada Tabel 3 Berdasarkan data tersebut, hamper seluruh mahasiswa memahami setiap pernyataan kompetensi/indikator pada rubrik lebih dari $82 \%$.

Berdasarkan instrumen penilaian kinerja (Performance Assesment) praktikum ekologi tumbuhan diperoleh profil kompetensi mahasiswa sebagaimana terlihat pada tabel 4. Dari rata-rata kinerja praktikum dan profil rata-rata kompetensi melakukan praktikum hampir seluruh mahasiswa kompeten dalam melakukan praktikum ekologi tumbuhan. 
Tabel 3. Hasil Penilaian Kompetensi Melakukan Praktikum

\begin{tabular}{ccc}
\hline $\begin{array}{c}\text { Kompetensi mahasiswa berdasarkan } \\
\text { materi praktikum }\end{array}$ & Rata-rata Kompetensi Praktikum & Persentase (\%) \\
\hline \hline & & \\
Perbedaan tempat tumbuh Intraspesifik & 1,3862 & $81,22 \%$ \\
dan interspesifik, & 1,7435 & $86,76 \%$ \\
Alelopati & 1,8011 & $90,06 \%$ \\
Daur karbon & 1,8732 & $91,04 \%$ \\
Analisis vegetasi (metode kuadran) & 1,6856 & $84,24 \%$ \\
Suksesi & 1,7987 & $88,02 \%$ \\
\hline
\end{tabular}

Dari tabel 4 di atas kompetensi mahasiswa berdasarkan materi praktikum persentasi paling tinggi pada materi daur karbon sebesar 90,06\% dan yang paling rendah pada materi perbedaan tempat tumbuh $81,22 \%$. Kegiatan pelaksanaan pembelajaran praktikum menekankan pada pemberian pengalaman belajar secara langsung melalui penggunaan dan pengembangan keterampilan proses, sehingga performance assessment menjadi sangat penting. Proses penilaian dilakukan dengan langkah-langkah: perencanaan penilaian, pengumpulan informasi melalui sejumlah bukti yang menunjukkan pencapaian hasil belajar, pelaporan, dan penggunaan informasi tentang hasil belajar.

Kriteria pemilihan aspek-aspek yang dinilai dalam instrumen penilaian kinerja (performance assessment) dapat mengukur kompetensi mahasiswa berdasarkan materi-materi pada kegiatan praktikum ekologi tumbuhan. Menurut Marhaeni, penilaian kinerja diartikan sebagai suatu prosedur penilaian yang menggunakan berbagai bentuk tugas untuk memperoleh informasi tentang apa dan sejauh mana pencapaian dalam suatu Program. Penilaian didasarkan pada unjuk kinerja (performance) yang ditunjukkan dalam menyelesaikan suatu tugas atau permasalahan yang diberikan, seperti memaparkan pengetahuan, menggunakan penalaran, mendemonstrasikan skill ataupun produk, dan sikap/afektif.

\section{KESIMPULAN}

Berdasarkan hasil penelitian dapat disimpulkan, produk yang dihasilkan dalam penelitian pengembangan ini adalah instrumen penilaian kinerja. instrumen penilaian kinerja ini berisikan aspek-aspek penilaian dalam kegiatan praktikum ekologi tumbuhan, yang meliputi tahap persiapan praktikum, pelaksanaan praktikum, dan kegiatan akhir praktikum. Tahapan penelitian mulai dari analisis kebutuhan, saran dan pertimbangan dari pakar dan mahasiswa, serta uji coba di lapangan dapat diperoleh rubrik asesmen kompetensi melakukan praktikum yang valid dan reliabel, sehingga layak dan dipercaya untuk digunakan sebagai rubrik asesmen. Hampir seluruh mahasiswa berkompeten melakukan praktikum ekologi tumbuhan. Rata-rata mahasiswa kompeten dalam melakukan praktikum perbedaan tempat tumbuh $(81,22 \%)$, intraspesifik dan interspesifik $(86,76 \%)$, alelopati $(90,06 \%)$, daur karbon $(91,04$ $\%)$ dan analisis vegetasi (metode kuadran) $(84,24$ $\%)$, dan suksesi (88,02 \%).

\section{DAFTAR PUSTAKA}

Akbar, Sa'dun, 2013. Instrumen Perangkat Pembelajaran. Penerbit: Pt Remaja Rosdakarya. Bandung

Asmawi Zainul. (2001). Alternative Assessment. Jakarta: PAU untuk Peningkatan Pengembangan Aktivitas Instruksional.

Azwar, S. (2010). Reliabilitas dan Validitas.

Yogyakarta : Pustaka Pelajar

Berk, R.A. 1986. Penilaian kinerja. London: The Johns Hopkins Press Ltd.

Depdiknas. Subana. 2000. Statistik Pendidikan. Bandung: Pustaka Setia.

Herdiana, Dian. (2008). Implementasi Penilaian Kinerja (performance assesment) 
JURNAL PELITA PENDIDIKAN VOL. 5 NO. 3

Halaman : $282-289$

dalam Meningkatkan Aplikasi Pengetahuan Fisika. Skripsi Sarjana Strata 1 pada FPMIPA UPI Bandung : tidak diterbitkan.

LAN. (1992). Penilaian Kinerja Pegawai. Jakarta:

LAN

Nazarudin, Mohamad Riza (2009). Penggunaan

Asesmen Kinerja Terhadap Siswa

Sma Kelas X Dalam Praktikum Tik Pada

Kompetensi Perangkat Lunak

Pengolah Angka. Skripsi strata 1 FPMIPA

UPI Bandung: tidak diterbitkan

Purwanto, N. 2009. Prinsip-prinsip dan Teknik

Evaluasi Pengajaran.Penerbit:

Rosda. Bandung

Setiadi, H. (2006). Penilaian Kinerja. Jakarta: Pusat

Penilaian Pendidikan Balitbang

Sugiyono. (2012). Metode Penelitian Kuantitatif Kualitatif dan R\&D. Bandung: Alfabeta.

Zainul. A. (2005). Asesmen Alternatif untuk Mendukung Belajar dan Pembelajaran. Makalah disampaikan dalam Seminar HEPI di Yogyakarta.

Zainul. A. (1999). Diklat Kuliah Assesmen Pendidikan. Bandung: UPI 